\title{
USE OF A PBL-APPROACH TO DEVELOP AND TO ASSESS GENERIC COMPETENCES IN A MASTER'S DEGREE IN MECHANICAL ENGINEERING
}

\author{
J. Carballeira, M. Tur, A.J. Besa, J. Albelda, J.E. Tarancón, J. Martínez-Casas, \\ F.D. Denia, J.J. Ródenas \\ Departamento de Ingeniería Mecánica y de Materiales, Universitat Politècnica de València \\ (UPV) (SPAIN)
}

\begin{abstract}
This paper presents the work carried out within the framework of an educational innovation and improvement project developed during the last two years in the Master's Degree in Mechanical Engineering at the Technical University of Valencia (UPV). One of the main objectives of this project is the development and implementation of new methodologies for the evaluation of generic competences. Among these new methodologies, there is an approach through project-based learning, which allows for the incorporation of the assessment of some generic competences that was not done previously in a proper way. Therefore, several subjects have been coordinated, a new type of Master's Thesis has been proposed, with the collaboration of a company, and new assessment tools have been designed.
\end{abstract}

Keywords: assessment, generic competences, Master's Thesis.

\section{INTRODUCTION}

The Master's Degree in Mechanical Engineering has been taught in the Technical University of Valencia (UPV) in its actual version since 2014. The reports on the quality assessment of this Degree have been very positive in the recent years, but some improvements have been pointed out. These improvements refer mainly to the development and the assessment of generic competences.

The importance of generic competences has been emphasized in the higher education frameworks around the world thanks to the international accreditation systems such as ABET [1], and also because of the demands of the employers to have better information on the skills of the students to optimize the recruitment [2]. Accordingly, the Technical University of Valencia devised an institutional project to foster innovative learning and teaching activities related to generic competences back in 2014 [3]. A set of 13 key generic competences were identified, which include and group most of the 31 generic competences determined in the Tuning project [4].

The following competences were reported to be insufficiently developed and assessed within the Master's Degree programme. They are labelled using the Tuning project terminology to make them understandable for all the readers. The number in brackets refers to the position given in the UPV project:

- The ability to work in a team (СТ06)

- The ability to act on the basis of ethical reasoning and the commitment to the conservation of the environment (СТ07)

- Capacity to learn and stay up-to-date with learning (CT11)

- The ability to plan and manage time (CT12)

In order to address these deficiencies, an innovative educational project was devised. The use of a learning-oriented active methodology is, in the authors' opinion, essential to force the students to put their skills into play, so that the required competences can be practiced and evaluated [5]. The main idea in this project was to use the Project Based Learning approach to introduce some activities along the Degree, and also a Master's Thesis, that would help the students to develop these generic competences. This methodology is suitable to develop generic competences, moreover when it is combined with cooperative work [6]. 


\subsection{Goals}

Therefore, the main goals of this innovation were:

- To define a Master's Thesis using a PBL approach so that it would be stimulating for the students, and that it would provide the possibility to work on and to assess different generic competences.

- To coordinate the Master's Degree subjects to plan a multidisciplinary project in which to practice the PBL approach during the studies.

- To design a methodology and to develop some instruments to assess the generic competences related to these activities.

\section{METHODOLOGY}

Two type of activities were planned. First, some of the subjects in the Degree related to Mechanical Design and Structural Integrity have to coordinate with each other to set out a design project that needs from the knowledge and the techniques that are being learnt in these subjects [7].

There are several subjects that deal with numerical simulation and mechanical design that are suitable for this multidisciplinary project such as:

- Computer Aided Design using the Finite Element Method: numerical simulation of flexible bodies with linear elastic behaviour.

- Mechanical Design using Composites: numerical simulation of composites and structural integrity.

- Fatigue and Damage Tolerance: structural integrity under variable loads.

- Non-Linear Structural Mechanics: numerical simulation of bodies in contact and with large displacements.

- Condition Monitoring and Noise Control: analysis of mechanical systems using mechanical vibrations.

- Vehicle Dynamics: numerical simulation of road and railway vehicles.

Some of the contents of the subjects that finally take part in this project are transferred to this activity, together with the corresponding grade in the subject.

Second, alongside with Master's Degree main learning outcomes, related to numerical simulation and mechanical design, a "design challenge" can be proposed as a Master's Thesis. This challenge should concern a real problem with multiple solutions possible, so that it is stimulating enough for the students to seek and to learn the knowledge and the methods necessary to successfully complete the design [8]. Furthermore, it should involve the generic competences aforementioned, so that the students can practice and develop them. Finally, the assessment of these competences will be done by using different evaluation strategies, taking advantage of the rubrics supplied in the institutional project [3], or by searching for similar interventions in the literature [9].

\section{RESULTS}

In this section, the activities and the assessment of the generic competences involved will be described.

\subsection{Multidisciplinary project}

The subjects on "Fatigue and Damage Tolerance" together with "Non-Linear Structural Mechanics" have coordinated to transfer $50 \%$ of their learning outcomes into a common project. This project consists of studying a real component which has failed during service. The students are divided into teams and they must collaborate in order to complete a set of reports during the year. To carry these reports out, the students have to work on some generic competences, what also provides several opportunities to assess them using the rubrics of the UPV project [3]. 


\subsection{Master's Thesis}

A Master's Thesis has been offered to the students in which they are challenged to complete a real industry project. This Thesis has been named "Design Challenge" and it has been formulated in collaboration with the company Stadler, which is a train manufacturer that has a factory close to the university [10]. The students will have to work in a team to set the deadlines and organize the tasks, and to look for the methods and the materials that can help them to find a feasible solution with the support of their academic supervisor. There is a final contest in which they have to show their solutions to a jury, which is composed of experts from the company and some lecturers from the Degree. The assessment of the generic competences that the students will put into play to achieve a successful solution is shared between the supervisor, the jury and themselves.

\subsubsection{Assessment of the generic competences in the Master's Thesis}

A strategy has been set up to assess the generic competences during the Master's Thesis development. The academic supervisor will be the responsible for the monitoring of the performance of the teams and their assessment. Different methods will be used to evaluate these competences:

- Peer-assessment - The supervisor will give the students a questionnaire that they will have to answer individually regarding the team dynamics and performance.

- Self-assessment - The same questionnaire will include some questions on the student's performance.

- The supervisor will also schedule some meetings during the project development, every 2-4 weeks, with the team to track their work.

For some of the competences, the jury of the Master's Thesis will provide further assessment by studying the documents and asking the necessary questions during the oral dissertation.

As an example, the strategy and the assessment instruments for СT07 (The ability to act on the basis of ethical reasoning and the commitment to the conservation of the environment) are presented below.

In the rubric of the UPV regarding this competence, a set of outcomes or indicators are defined for this Master's Degree level:

- CT07-I1 - The student resolves, through dialogue, some need linked to coexistence based on the desired ethical values.

- CT07-12 - The student coordinates respectful comprehensive actions in the professional field.

- CT07-13 - The student evaluates comprehensive professional actions in accordance with available material and human resources in terms of respect for the social, economic, and environmental context.

The following instruments, and how to collect the evidence, are devised. For the first outcome:

- Students: They have to fill a peer-assessment and a self-assessment questionnaire about any conflicts that may have appeared in the team.

- Supervisor: If there have been any conflicts in the team, the supervisor will ask them how they have resolved these disagreements during the periodic meetings.

For the second outcome:

- Students: They have to complete a questionnaire about the other members of the team. They will be asked if the other members fulfil their assignments in a professional way, if they participate actively in the decisions about the deadlines and goals of the team, and if they accept the rules and they are not using devious methods to complete the project.

- Supervisor: The use of legal software and the fulfilment of the project requirements will be monitored by the supervisor.

For the third outcome, the Jury will study the documents and they will ask as many questions as necessary to evaluate if social, economic and environmental criteria have been considered further than technical ones, in order to choose the materials and the manufacturing processes, for instance. 


\section{CONCLUSIONS}

The main conclusions that can be drawn so far from the work developed in this innovative educational project are:

- The coordination of the teaching staff involved in the Degree is essential to be able to work on and to assess generic competences in a consistent way.

- Active methodologies offer more opportunities for the development and the evaluation of generic competences.

- The collaboration between the university and the industry can be very interesting to produce stimulating and realistic learning activities.

\section{ACKNOWLEDGEMENTS}

The authors acknowledge the financial contribution by the Universitat Politècnica de València through the project PIME/2018/DPTO.IMM.

\section{REFERENCES}

[1] A. Naimpally, H. Ramachandran, and C. Smith.. Lifelong Learning for Engineers and Scientists in the Information Age. Amsterdam: Elsevier, 2012.

[2] J. Andrews and H. Higson, "Graduate employability, 'Soft skills' versus 'Hard' business knowledge: A European study," Higher Education in Europe, vol. 33, pp. 411-422, 2008.

[3] Universitat Politécnica de València (UPV), "Proyecto institucional sobre competencias transversales," Accessed 27 June, 2019. Retrieved from http://www.upv.es/contenidos/COMPTRAN/

[4] Tuning project, "Generic competences," Accessed 27 June, 2019. Retrieved from https://www.unideusto.org/tuningeu/competences/generic.html

[5] J. Carballeira et al., "Chapter 5: Assessment of problem-solving skills and capacity for applying knowledge in practice in subjects related to mechanical and materials engineering." in Advances in Higher Education (J. Doménech i De Soria, J. Lloret Mauri, M.C. Vincent Vela, E. Zuriaga Agustí, E. Poza Plaza eds.), pp. 71-88, Valencia: Editorial UPV, 2016.

[6] A. Villa and M. Poblete, "Evaluación de competencias genéricas: principios, oportunidades y limitaciones," Bordón. Revista de pedagogía, vol. 63, no. 1, pp. 147-170, 2011.

[7] H.S. Barrows, "A Taxonomy of problema-based learning methods," Medical Education, vol. 20, no. 6, pp. 481-486, 1986.

[8] A.C. Metta and C.C. Constantinou, "The technology fair: a project-based learning approach for enhancing problem solving skills and interest in design and technology education," International Journal of Technology and Design Education, vol. 18, pp. 79-100, 2007.

[9] Y. Ye-Lin et al., "Análisis del empleo de la metodología aprendizaje basado en proyectos como herramienta de desarrollo y evaluación de múltiples competencias transversales. Aplicación en grupos numerosos de asignaturas en la rama de ingeniería." in Congreso Nacional de Innovación Educativa y Docencia en Red (IN-RED 2017) (Instituto Ciencias de la Educación del Universitat Politècnica de València eds.), Valencia: Editorial UPV, 2017.

[10] Cátedra Stadler, "Nuevas ideas para el diseño de estructuras de capotas y cabinas," Accessed 23 March, 2020. Retrieved from https://www.catedrastadler.com/copia-de-convocatoria-de-trabajos 